\title{
Seminal plasma proteins interacting with sperm surface revert capacitation indicators in frozen-thawed ram sperm
}

Alba Ledesma ${ }^{\mathrm{a}}$, Estela Fernández-Alegre ${ }^{\mathrm{b}}$, Adriana Cano $^{\mathrm{c}}$, Federico Hozbor ${ }^{\mathrm{c}}$, Felipe Martínez-Pastor $^{\mathrm{b}}$, Andreína Cesari ${ }^{\mathrm{d}}$

${ }^{a}$ Facultad de Ciencias Agrarias, Universidad Nacional de Mar del Plata, Ruta 226 km 73.5, Balcarce (7620), Argentina; ${ }^{b}$ Instituto de Desarrollo Ganadero y Sanidad Animal (INDEGSAL) y Departamento de Biología Molecular (Biología Celular), Universidad

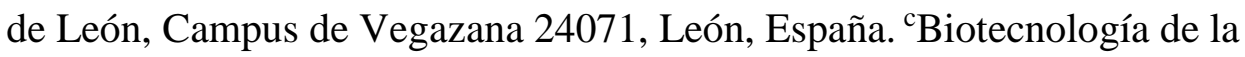
Reproducción, Departamento de Producción Animal, Instituto Nacional de Tecnología Agropecuaria (INTA), Balcarce, Argentina; ' Biología de Microorganismos y Gametas, Instituto de Investigaciones Biológicas-CONICET, Universidad Nacional de Mar del Plata, Funes 3250, Mar del Plata (7600), Argentina. *This authors contributed in equal parts.

Corresponding author: Federico Hozbor, Instituto Nacional de Tecnología Agropecuaria, Ruta 226 km 73.5, CP 7620 Balcarce, Argentina. E-mail: fhozbor@hotmail.com; hozbor.federico@inta.gob.ar 


\section{Abstract}

This study was conducted to evaluate the effects of interacting seminal plasma proteins (iSPP) obtained by AV or EE on frozen-thawed ram sperm in order to test the hypothesis whether this fraction could be sufficient to emulate the effect of complete seminal plasma (SP). Additionally, we evaluated whether this proteins has a differential effect between spermatozoa from high and low fertility rams and between breeding and non-breeding seasons. We assessed sperm motility, quality parameters (intracellular reactive oxygen species, membrane fluidity, plasma membrane permeability and mitochondrial activity) and capacitation status. The main findings from this work were: i) iSPP had no effect on sperm motility, whereas SP (AV or EE) addition produced the highest values of total motility $(74.13 \pm 2.99$ and $72.27 \pm 2.99$ for AV and EE, respectively) and progressive motility (64.97 \pm 2.64 and $63.73 \pm 2.64$ for $\mathrm{AV}$ and $\mathrm{EE}$, respectively); ii) iSPP had no effect on sperm quality parameters ( $\mathrm{p}>0.05)$, but whole SP improved all parameters evaluated. Moreover, SP collected by AV yielded significantly higher viability $(44.60 \pm 2.87)$ and sperm with stable plasma membrane $(44.56 \pm 2.49)$ comparing with the addition of SP collected by EE $(35.80 \pm 2.47$ and $36.67 \pm 1.71$, respectively); iii) iSPP and SP collected by EE, but not by AV, reverted molecular signals of capacitation as protein tyrosine phosphorylation caused by freezing temperatures; iv) there were no effects of fertility or season in sperm quality parameters evaluated. This study demonstrated that, although the iSPP have a clear decapacitating effect, including the ability to revert cryo-capacitation indicators, they are not sufficient to emulate the effects of complete SP regarding sperm functional parameters.

Keywords: Capacitation; Post-thaw sperm quality; Seminal plasma. 


\section{Introduction}

The cryopreservation process, involving cooling, freezing and thawing produce serious detrimental changes in ram sperm function (Ari et al., 2011). Sperm cryoinjury includes the reduction of viability, motility and mitochondrial membrane potential, chromatin damage, increase in the production of reactive oxygen species, activation of apoptosis (Said et al., 2010) and perhaps the most important cryoinjury, the premature induction of a capacitation-like status (Bailey et al., 2003). All of these alterations result in reduced longevity of the cryopreserved spermatozoa within the female reproductive tract, decreasing the likelihood of successfully interact with the oviduct or fertilize the ovum.

Seminal plasma (SP) is a mixed secretion from several glands of the male reproductive tract. Supplementation of frozen/thawed ram sperm with SP has been noted to improve sperm characteristics including motility, viability (Ollero et al., 1997; DomínguezRebolledo et al., 2007; Maxwell et al., 2007; Domínguez et al., 2008) and the ability to penetrate the cervical mucus (Graham, 1994; Maxwell et al., 1999; El-hajj Ghaoui et al., 2007; Leahy et al., 2010). Moreover, whole ram SP addition improved cryopreservation of goat semen (Ari and Daskin, 2010). Dott et al. (1979) observed that the effects of SP on sperm cells lasted even after the removal of SP.

The beneficial impact of SP on sperm has been attributed to its proteic components, since seminal plasma proteins (SPP) are able to increase sperm resistance against cold shock (Barrios et al., 2000; Pérez-Pé et al., 2001; Colás et al., 2009) and stimulate sperm function and fertilising ability (Maxwell et al., 2007). It has already been shown that SPP support survival of ram spermatozoa acting not only at the plasma membrane 
level but also by inhibiting capacitation (Desnoyers and Manjunath 1992; Barrios et al., 2005) and apoptosis-like changes (Mendoza et al., 2013).

Bernardini et al. (2011) demonstrated that a fraction of SPP with affinity by the sperm membrane was able to repair ultrastructural damage and improve motility of frozen/thawed ram sperm. This fraction, enriched in RSVP14 and RSVP22 proteins, was called interacting SP proteins (iSPP). Previous work has demonstrated that these proteins were partially able to protect and repair ram sperm membrane against coldshock damages and detrimental effects of cryopreservation process (Barrios et al., 2000; Pérez-Pé et al., 2001; Barrios et al., 2005; Ari and Daskin 2010) as well as to maintain fresh sperm in a decapacitated state (Mendoza et al., 2013). Domínguez et al. (2008) observed that the composition and protein concentration of SP varies according to season. Moreover, in a recent work we noted that ram iSPP varies according to the collection method applied and that the iSPP collected by electroejaculation (EE) has a greater concentration of low molecular weight proteins, such as those considerate as crioprotectans, than the same fraction obtained by artificial vagina (AV) (Ledesma et al., 2014).

With this background, in this work we evaluated the effect of addition of iSPP obtained by AV or EE to thawed spermatozoa from ram with low or high fertility and tested the hypothesis that it could be sufficient to emulate the effect of complete SP. Additionally, we evaluated whether the iSPP had a differential effect on sperm quality between breeding and non-breading season.

\section{Materials and Methods}

\section{Reagents}


Flow cytometry consumables (including the sheath fluid) were purchased from BD Biosciences (San Jose, CA, USA). The rest of the chemicals were acquired from Sigma. Chemicals were of the highest grade available. PBS was prepared in milli-Q water: 136.9 mM NaCl, $2.7 \mathrm{mM} \mathrm{KCl}, 0.9 \mathrm{mM} \mathrm{CaCl}_{2}, 0.5 \mathrm{mM} \mathrm{MgCl}_{2}, 7 \mathrm{mM} \mathrm{Na}_{2} \mathrm{HPO}_{4}, 1.25$ $\mathrm{mM} \mathrm{NaH} 2 \mathrm{PO}_{4}, 1.5 \mathrm{mM} \mathrm{KH} 2 \mathrm{PO}_{4}$ and $1 \mathrm{~g} / \mathrm{PVA}(290 \mathrm{mOsm} / \mathrm{kg} ; \mathrm{pH}$ 7.2).

\section{Frozen semen}

All experiments were performed using frozen spermatozoa from 10 adult Assaf rams divided in two groups of five rams each, accordingly to their fertility in low $(35.3 \pm 3.0 \%)$ and high $(60.4 \pm 1.5 \%)$ fertility. Frozen semen was supplied by OVIGEN (Centro de Selección y Mejora Genética de Ovino y Caprino de Castilla y León, Toro, Spain)

\section{Animals}

All animal procedures were in accordance with the Spanish Animal Protection Regulation RD 1201/2005, according to European Union Regulation 2003/65. Eight mature Assaf rams were used for obtaining SP and iSPP. Two experiments were carried out, one in autumn (breeding) and the other in spring (non-breeding season).

\section{Seminal plasma and interacting seminal plasma proteins: collection and processing}

SP and iSPP were obtained from all males by AV and EE according to Marco-Jiménez et al. (2005) separately by two days between methods. We performed one seminal collection during autumn (breeding season) and one seminal collection during spring (non-breeding season). Ejaculates with total motility $\geq 80 \%$ were pooled by collection method and then split in two parts. One of them was used to obtain SP and the other one was used to obtain the iSPP. Briefly, for obtaining SP, half of the pooled semen was 
centrifuged twice $\left(2000 \mathrm{x} g\right.$ for $15 \mathrm{~min}$ at $\left.4{ }^{\circ} \mathrm{C}\right)$. The clear supernatant (SP) was recovered, filtered $(0.22 \mu \mathrm{m})$ and kept at $-80{ }^{\circ} \mathrm{C}$ until use. The other half of the semen pool was used to recover iSPP. Ejaculates were washed 10 times with PBS to remove excess of unbound SP (800 x $g, 10 \mathrm{~min})$. Sperm free from SP were incubated with 200 $\mu \mathrm{l}$ buffer $10 \mathrm{mM}$ Glycine- $\mathrm{HCl} \mathrm{pH} 3$ (20 min, room temperature, with agitation). Finally, sperm were centrifuged and the supernatant was conserved and neutralized with $5 \mu 1$ Tris-HCL $2 \mathrm{M} \mathrm{pH} \mathrm{9.5.} \mathrm{Protein} \mathrm{concentration} \mathrm{of} \mathrm{SP} \mathrm{and} \mathrm{iSPP} \mathrm{were} \mathrm{assessed} \mathrm{according} \mathrm{to}$ the method described by Bradford (1976), using BSA for the standard curve. The concentration of proteins eluted with low $\mathrm{pH}$ buffer from the sperm surface coming from a known volume of SP was calculated as $\mathrm{mg} / \mathrm{ml}$.

\section{Experimental design}

Three straws of males of low or high fertility were randomly thawed by immersion in a water bath $\left(37^{\circ} \mathrm{C}, 20 \mathrm{~s}\right)$, layered over $1 \mathrm{~mL}$ Androcoll- $\mathrm{O}^{\mathrm{TM}}$ colloid and centrifuged, to remove dead cells and SP ( $800 \times \mathrm{x}$ by 5 minutes and then $1200 \times \mathrm{x}$ by 10 minutes). The supernatant was removed and the remaining pellet was suspended in $250 \mu \mathrm{l}$ of PBS and centrifuged again ( $800 \times \mathrm{x} g, 5$ minutes). The resulting sperm pellet was resuspended in PBS and the concentration and motility patterns were calculated. We performed four experimental replicates with frozen sperm of rams with low fertility and four experimental replicates with frozen sperm of rams with high fertility during spring. The second experiment was performed in the same way in autumn. An aliquot $(160 \mu \mathrm{l})$ of sperm suspension $\left(10 \times 10^{6}\right.$ spermatozoa) was supplemented with $40 \mu \mathrm{L}$ of five different solutions ( $200 \mu \mathrm{l}$ of final volume) and incubated at $37{ }^{\circ} \mathrm{C}$ during one hour. The supplementation media were: 
- $40 \mu \mathrm{L}(20 \% \mathrm{v} / \mathrm{v})$ of SP collected by AV (40 $\mu \mathrm{l}=0.6 \mathrm{mg}$ protein for spring SP or $1.4 \mathrm{mg}$ for autumn SP)

- $\quad 40 \mu \mathrm{L}(20 \% \mathrm{v} / \mathrm{v})$ of SP collected by EE $(40 \mu \mathrm{l}=0.48 \mathrm{mg}$ protein for spring SP or $1.2 \mathrm{mg}$ for autumn SP)

- $40 \mu \mathrm{L}$ of iSPP from AV collection (7 $\mu \mathrm{g}$ for spring collection or $23 \mu \mathrm{g}$ for autumn collection) in PBS $0.5 \%$ fructose.

- $\quad 40 \mu \mathrm{L}$ of iSPP from EE collection (3.2 $\mu \mathrm{g}$ for spring collection or $29 \mu \mathrm{g}$ for autumn collection) in PBS $0.5 \%$ fructose.

- Negative control: $40 \mu \mathrm{L}$ of PBS $0.5 \%$ fructose.

The amount of iSPP was selected on the basis of the proportional amount of proteins provided by an equivalent volume of complete SP. The concentration of proteins in SP was $35.0 \mathrm{mg} / \mathrm{ml}$ and $30.0 \mathrm{mg} / \mathrm{ml}$ for AV and EE, respectively, in autumn and 15.0 $\mathrm{mg} / \mathrm{ml}$ and $12.0 \mathrm{mg} / \mathrm{ml}$ for $\mathrm{AV}$ and $\mathrm{EE}$, respectively, in spring. The concentration of proteins in iSPP in autumn was $7.8 \mathrm{mg} / \mathrm{ml}$ and $5.8 \mathrm{mg} / \mathrm{ml}$ for AV and EE, respectively, and in spring it was $0.9 \mathrm{mg} / \mathrm{ml}$ and $0.8 \mathrm{mg} / \mathrm{ml}$ for AV and EE, respectively.

Fructose concentration was chosen based on the concentration previously measured by us in SP (unpublished data).

\section{Sperm analyses}

After thawing, the following analyses were made: motility parameters with CASA system, quality parameters by flow cytometry and capacitation status (tyrosine phosphorylation) by Western blotting. After one hour of incubation at $37^{\circ} \mathrm{C}$, those parameters were evaluated in treatments and negative control. 


\section{Motility parameters}

Motility parameters were estimated by computer-assisted sperm motility analysis using a CASA system (ISAS 1.0.4; Proiser SL, Valencia, Spain). A Makler counting chamber (10 $\mu \mathrm{m}$ depth; Haifa Instruments, Israel), warmed up to $37^{\circ} \mathrm{C}$, was filled with $5 \mu \mathrm{L}$ of sample and examined with a phase contrast microscope (Nikon E400; negative contrast optics). At least four fields and 200 cells were recorded at $10 \times$ using a video camera (Basler A312f, Basler Vision Components, Exton, PA, USA), at 53 frames/s and an acquisition time of $1 \mathrm{~s}$. The kinematic parameters recorded for each spermatozoon were: total motility (TM; \%), progressive motility (PM; \%), velocity path average (VAP; $\mu \mathrm{m} / \mathrm{s}$ ), straight-line velocity (VSL; $\mu \mathrm{m} / \mathrm{s}$ ), curvilinear velocity (VCL; $\mu \mathrm{m} / \mathrm{s}$ ), linearity (LIN; \%), straightness (STR; \%), wobble (WOB; \%), amplitude of the lateral movement of the head $(\mathrm{ALH} ; \mu \mathrm{m})$ and beat-cross frequency $(\mathrm{BCF} ; \mathrm{Hz})$..

\section{Quality parameters}

Stock probes were as follows: Hoechst 33342 (Sigma B2261) 8.9 mM in Milli-Q water; Propidium iodide (PI) (Sigma P4170) 1.5 mM in Milli-Q water; Mitotracker Deep Red 633 (Invitrogen M22426) $100 \mu \mathrm{M}$ in DMSO; Dichlorodihydrofluorescein diacetate (CM-H ${ }_{2}$ DCFDA) (Invitrogen C6827) 1 mM in DMSO; YO-PRO-1 iodide (491/509) (Invitrogen Y3603) $1 \mathrm{mM}$ in DMSO; Merocyanine 540 (M540; Sigma) $1 \mathrm{mM}$ in DMSO. All solutions were kept in the dark at $-20{ }^{\circ} \mathrm{C}$ until needed.

\section{Flow cytometer configuration}

Flow cytometric analyses were carried out on a Cyan Adp flow cytometer (Beckman Coulter, Inc., Brea, USA). The three lasers of the cytometer were used to excite the different fluorochromes. A 325-nm helium-cadmium UV laser was used for exciting the Hoechst 33342, a 488-nm argon-ion laser was used for exciting YO-PRO-1, CM- 
$\mathrm{H}_{2}$ DCFDA, M540 and PI and a 633-nm helium-neon laser was used for exciting MitoTracker Deep Red. Forward-scatter light (FSC) and side-scatter light (SSC) signals plus the fluorescence light of each fluorochrome were acquired. A 530/28 filter was used for the fluorescence from YO-PRO-1 and CM-H 2 DCFDA, a 575/25 for M540, a 670LP filter for PI , a 424/44 for Hoechst 33342 and 620/20 for MitoTracker deep red. The acquisition was controlled using the Summit V4.3.02 software. All the parameters were read using logarithmic amplification. An acquisition template was set up in the software in order to discriminate spermatozoa from debris within the events acquired. FSC/SSC and Hoechst 33342 vs. PI dot-plots were used to discard debris. A total of 5.000 spermatozoa were acquired per sample, with a flow rate of 200 cells/s (MartínezPastor et al., 2010). The analysis of the flow cytometry data was carried out using Weasel v. 3.2 (WEHI, Melbourne, Australia).

\section{Plasma membrane permeability and mitochondrial activity}

Variations of plasma membrane permeability were assessed using the YO-PRO-1/PI combination (PI identifies YO-PRO-1+ spermatozoa with extensive membrane damage) and sperm mitochondrial function was assessed using MitoTracker deep red, this dye is readily sequestered in mitochondria and emits red fluorescence in active mitochondria (high mitochondrial membrane potential) Samples were prepared at $10^{6} \mathrm{~mL}^{-1}$ in PBS with $100 \mathrm{nM}$ YO-PRO-1, $3 \mu \mathrm{M}$ PI and $100 \mathrm{nM}$ MitoTracker deep red. After $15 \mathrm{~min}$ at $37^{\circ} \mathrm{C}$ in the dark, samples were analysed. Considering membrane permeability, spermatozoa were classified into: viable, normal membrane permeability (YO-PRO-1/PI-); viable, increased membrane permeability or apoptotic (YO-PRO-1+/PI-); and dead (YO-PRO-1+/PI+). MitoTracker+/YO-PRO-1- were considered as viable sperm with high mitochondrial membrane potential (normal); MitoTracker-/YO-PRO-1- were considered as viable cells with decreased mitochondrial membrane potential and YO- 
PRO-1+ were considered as apoptotic/dead cells (Fernández-Gago et al., 2013). Data were expressed as the percentage of spermatozoa in each category. Intracellular reactive oxygen species (ROS)

CM- $\mathrm{H}_{2}$ DCFDA was used for the detection of intracellular ROS. CM- $\mathrm{H}_{2}$ DCFDA is oxidized to dichlorofluorescein (DCF), which emits fluorescence at $530 \mathrm{~nm}$ in response to the $488 \mathrm{~nm}$ excitation. This fluorescent probe was combined with PI for removing the non-viable population from the analysis (Dominguez-Rebolledo et al., 2011). Samples were prepared at $10^{6} \mathrm{~mL}^{-1}$ in PBS with $1 \mu \mathrm{M} \mathrm{CM}-\mathrm{H}_{2}$ DCFDA and $2.5 \mu \mathrm{g} / \mathrm{ml}$ PI. After 15 min at $37^{\circ} \mathrm{C}$ in the dark, samples were analysed. The median of the green fluorescence intensity was used for analysis, after excluding PI+ events (dead spermatozoa).

\section{Membrane fluidity}

M540 binds preferentially to membranes with loosely packed lipids, whereas YO-PRO1 stains the nuclei of cells with increased plasma membrane permeability ("apoptotic" or dead). Samples were prepared at $10^{6} \mathrm{~mL}^{-1}$ in PBS with $2.7 \mu \mathrm{M}$ M540 and $0.1 \mu \mathrm{M}$ YO-PRO-1. After 15 min at $37^{\circ} \mathrm{C}$ in the dark, samples were analysed. Spermatozoa belonged to one of three populations: high YO-PRO-1 fluorescence (dead or increased membrane permeability); low M540 fluorescence and low YO-PRO-1 fluorescence (lower membrane fluidity); high M540 fluorescence and low YO-PRO-1 fluorescence (higher membrane fluidity) (Fernández-Gago et al., 2013).

\section{Assessment of capacitation status by Western blot (tyrosine phosphorylation)}

Aliquots containing $5 \times 10^{6}$ cells of each treatment and negative control were centrifuged at $7500 \times \mathrm{g}$ for $5 \mathrm{~min}$ at $4{ }^{\circ} \mathrm{C}$, and the supernatant was discarded. Samples were mixed with 5x Laemmli sample buffer under reducing conditions (100 mM DTT) and boiled. 
Finally, extracts were incubated at $100{ }^{\circ} \mathrm{C}$ for $5 \mathrm{~min}$. Solubilised proteins were separated by electrophoresis on 10\% (w/v) acrylamide SDS-PAGE (Laemmli, 1970) and electrotransferred onto Immun-Blot PVDF membranes (BIO-RAD). Non-specific binding sites on membranes were blocked with 5\% skimmed milk (w/v) in TBS-T (10 $\mathrm{mM}$ Tris- $\mathrm{HCl}, \mathrm{pH} 8.0,120 \mathrm{mM} \mathrm{NaCl}$ and $0.05 \%$ Tween 20) for $1 \mathrm{~h}$ at room temperature. Phosphorylated tyrosines were immunodetected by incubating with the primary antibody (Antiphosphotyrosine clone 4G10 monoclonal mouse, Millipore; 1:2000 in blocking solution) overnight at $4^{\circ} \mathrm{C}$ under agitation. After several washes in TBS-T, the membranes were incubated for $1 \mathrm{~h}$ at room temperature with a secondary goat anti-mouse IgG-HRP (1:5000 in blocking solution; GE, NA9311). Thereafter, the membranes were developed with a chemiluminescence reagent (ECL commercial kit, GE Amersham Biosciences) and detected on autoradiography films (Hyperfilm ${ }^{\mathrm{TM}}$ Amersham Biosciences). Digitalized Western blot images were analysed using ImageJ 1.43 (Rasband, W.S., ImageJ, U. S. National Institutes of Health, Bethesda, Maryland, USA, http://imagej.nih.gov/ij/, 1997-2015). The phosphorylation signal was evaluated as volume (area/intensity). Thereafter, blots were stripped during $20 \mathrm{~min}$ at $60{ }^{\circ} \mathrm{C}$ in stripping buffer (62.5 mM Tris-HCl, 2\% SDS, $100 \mathrm{mM} \beta$-mercaptoethanol, $\mathrm{pH}$ 6.5), reblocked and incubated sequentially overnight with a mouse monoclonal anti-tubulin antibody (1:5000) (Sigma) as a loading control. Secondary antibody incubation and development were performed as described above. Data normalization was performed by dividing the mean densities of phosphorylated proteins by the corresponding tubulin densities and expressed as a percentage.

\section{Statistical analysis}


Sperm parameters were compared by ANOVA using the MIXED procedure of the Statistical Analysis System version 8.2 (SAS Institute INC, Cary, NC). Data of thawed sperm evaluation were used as a covariable. The statistical model includes the effect of SP or iSPP, collection method, season and their interactions. Numeric results are expressed as least square means (LSM) \pm standard error of the means (SEM). Data were considered statistically significant when $\mathrm{p}<0.05$.

\section{Results}

\section{Effect of seminal plasma and interacting seminal plasma proteins on sperm}

\section{motility}

The highest percentages of TM, PM and WOB were observed when spermatozoa were incubated with SP obtained by AV or EE (Table 1), whereas incubation with iSPPs had no effects on these parameters. Addition of iSPP caused a decrease in VCL compared with control samples. However, when SP was added this decline was more pronounced. Regarding to VSL, incubation of spermatozoa with iSPP collected by AV had no effect in this parameter, in opposite to incubation with iSPP collected by EE or SP that caused a big drop in its values. Adding iSPP, regardless of the collection method, had no effect on STR, ALH and BCF, compared to the addition of SP which caused a decrease in those motility measures. Addition of any of the supplemented media had no effect on LIN. Contrary to what happened with VAP, where all media caused its decline. There were no differences between fertility and collection season in any of the motility variables evaluated $(\mathrm{p} \geq 0.05)$. 


\section{Effect of seminal plasma and interacting seminal plasma proteins on quality parameters evaluated by flow cytometry}

The analysis of physiological parameters using flow cytometry showed that all quality parameters were affected by treatment $(\mathrm{p}<0.0001)$ (Table 3$)$. We did not find effect of season or fertility on any of the variables studied ( $>0.05)$. Addition of SP collected by AV yielded significantly higher viability showed by an enhanced PI-/YO-PRO-1subpopulation comparing with the addition of SP collected by EE or any of the iSPP ( $\mathrm{p}<0.001)$. Viable sperm with stable plasma membrane (YO-PRO-1-/M540-) was higher in treatments composed by SP, being significantly higher when SP was collected by AV $(\mathrm{p}=0.014)$. The mitochondrial activity was affected by treatment, reaching the highest values of the sperm subpopulation YP-/MT+ when treatment was composed by any of the SPs. The presence of intracellular ROS was affected by treatment $(\mathrm{p}<.0001)(\mathrm{PI}-$ $/ \mathrm{H}_{2}$ DCFDA-) and was lower when SP was added reaching the lower values when SP was collected by AV. iSPP did not exert significant effects comparing to the control on the variables obtained from the flow cytometry analyses.

\section{Effect of seminal plasma and interacting seminal plasma proteins on tyrosine phosphorylation}

In order to evaluate the ability of iSPP obtained by AV and EE to revert molecular signals of capacitation caused by freezing temperatures, sperm protein tyrosine phosphorylation was analysed. Two protein bands of approximately 45 and $40 \mathrm{kDa}$ were detected. Densitometry quantification revealed that the phosphotyrosine signal induced by freezing and thawing was reverted after $1 \mathrm{~h}$ incubation with SP and iSPP proteins. We observed a significant decrease in the $45 \mathrm{kDa}$ and $40 \mathrm{kDa}$ bands in all 
treatments compared with control samples (Fig. 1). Season and fertility showed neither effects nor interaction with treatment.

\section{Discussion}

The present study reports that after thawing addition of iSPP had no effects in the majority of the sperm motility parameters evaluated by CASA system. However, it caused a decrease in curvilinear velocity and moreover, iSPP collected by EE caused a big drop in straight line velocity values. iSPP incubation neither exerts significant effects on sperm variables evaluated by flow cytometry. The evaluation of capacitation status through the quantification of phosphotyrosine signal revealed that the signal induced by freezing/thawing was reverted after incubation with SP and with the single addition of iSPP.

Gillan et al. (1997) demonstrated that the cryopreservation process causes changes in ram sperm membrane functionality equivalent to capacitation. Moreover, Pérez-Pé et al. (2002) proved that ram sperm capacitation is associated to protein tyrosine phosphorylation and that exposure of sperm cells to SP proteins prevents this capacitation, evidenced by the decrease of phosphotyrosine signal of protein bands of 45, 40 and $30 \mathrm{kDa}$. In the present work, we observed that addition of complete SP collected by AV and EE, and more interestingly, that only the fraction compose by their iSPP were able to decrease the phosphotyrosine signal of 45 and $40 \mathrm{kDa}$ bands in sperm cells. This is consistent with our previous observation related to the content of RSVP14 and RSVP20 in these samples (Ledesma et al., 2014b). Since, Barrios et al. (2005) hypothesized a possible decapacitating effect of these plasma proteins on sperm cells. This finding suggest that iSPP could be sufficient to reverse molecular signals of 
capacitation caused by freezing, perhaps acting through the inhibition of the signal transduction pathways of capacitation.

Only fully capacitated sperm are competent to undergo the acrosome reaction and fertilize an oocyte. Nevertheless, the life span of capacitated sperm is shorter than that of freshly ejaculated sperm (Holt and Medrano, 1997; Bailey et al., 2000). Thus, it is critically important that capacitation and ovulation occur in a temporal-spatial framework. Cryo-capacitated spermatozoa are less able to interact with the oviductal epithelium, exhibiting elevated metabolic rates and increased membrane fluidity and permeability. They undergo spontaneous acrosome reaction due to an uncontrolled influx of $\mathrm{Ca}^{2+}$ and lose their fertilizing ability before reaching the ampulla of the oviduct. Cryo-capacitation would then produce a sperm subpopulation with a shortened life span, effectively reducing the fertilization efficiency of the population as a whole. Likewise, it is very important that these decapacitating proteins can be removed from the sperm membrane to successfully fertilize an oocyte. From the results of the present work we can not confirm how long capacitation is delayed after iSPP addition and whether iSPP effect is further reversed. In order to propose a biotechnological use for the iSPP fraction it should be desirable that capacitation is delayed until sperm reaches the oviduct and interact with secretions of female genital tract.

iSPP had little effect on sperm motility evaluated by CASA, in contrast to previous findings of our group (Bernardini et al., 2011) and others (Rodrigues et al., 2013). These discrepancies could be attributed to the differences of the method used to assess motility and the incubation time evaluated. Since, the determination of motility in the present work was conducted by CASA which is a more objective and accurate tool than optical microscopy. In the present work, total and progressive motility were improved only by the addition of complete SP and these effects were regardless of the collection method 
of SP. Our previous results indicated that motility was improved by SP obtained in the breeding season compared to the non-breeding season (Dominguez et al., 2008). Moreover, Cardozo et al (2006) found a correlation between changes in SP protein composition and motility according to the season, which could not be confirmed in this work. However, having found that the control samples had higher values of VSL and VCL compared to treatments incubated with ISPP might confirm that these proteins have a decapacitating effect in sperm cells, since capacitated cells frequently presents a vigorous and non-progressive or nonlinear movement in association with the hyperactivation process, phenomenon seen during capacitation. On the other hand, Mortimer and Maxwell (1999) exposed that hypeactivated ram sperm cells also must show other parameters affected like linearity less than $30 \%$ and a maximum value of 9.0 $\mu \mathrm{m}$ in lateral head displacement and that was not observed in this work. iSPP had no effect on sperm quality parameters evaluated by flow cytometry. Meanwhile, the post-thawing addition of complete SP caused the best values in the sperm quality parameters studied. For the viable and normal membrane permeability sperm population (YO-PRO-1-/PI-), we also detected a greater effect of SP collected by AV than SP collected by EE, in contrast to our initial hypothesis. In quality parameters and sperm motility, addition of complete SP had better effects than addition of iSSP, in opposite of Bernardini et al., (2011) who demonstrated that sperm membrane ultrastructure was improved in sperm cells treated for 15 min with iSPP obtained by AV.

On the other hand, we didn't observe differences between collection seasons, in opposition of reported by Cardozo et al. (2006) and our group (Dominguez et al. 2008) and 
Taken all the results together we can conclude that, although the iSPP have a clear decapacitating effect, including the ability to revert tyrosine phosphorylation due to cryo-capacitation, they are not sufficient to emulate the effects of complete SP regarding sperm functional parameters. The protein concentration or the time of incubation might need adjustment, in order to allow a good interaction of the proteins with the spermatozoa. The results of this work may help to shed light on the effects of iSPP as a first step to the development of strategies for improving the quality and the fertilizing ability of cryopreserved ovine semen.

\section{Acknowledgements}

The authors are grateful with OVIGEN (Zamora, Spain) and Spanish National Association of Assaf Breeders for supplying the frozen semen samples; Ramiro González Montaña and Cristina Gómez Secco for their assistance with semen collection and handling of animals; Dr. Lucia Zalazar for their collaboration in methodological issues and Universidad de León, España and Universidad Nacional de Mar del Plata, Argentina. A. Ledesma was supported by Bec.Ar Program. PICT 2011-2155, PICT 2013-2015 and PICT-2012-2983. 


\section{References}

Ari, U.C. and Daskin, A., 2010. Freezing of Washed Angora Goat Semen with Extenders Added Bull or Ram Seminal Plasma. Kafkas Univ. Vet. Fak. Derg. 16, 233 237.

Ari, U.C., Kulaksiz, R., Öztürkler Y., 2011. Freezablity of Tushin Ram Semen Extended with Goat or Cow Milk Based Extenders. Reprod. Dom. Anim. 46, 975-979.

Bailey, J., Bilodeau, J., Cormier, N., 2000. Semen cryopreservation in domestic animals: a damaging and capacitating phenomenon J. Androl. 21, 1-7.

Bailey, J., Morrier, A., Cormier, N., 2003. Semen cryopreservation: successes and persistent problems in farm species. Can. J. Anim Sci. 83, 393-401.

Barrios, B., Pérez-Pé, R., Gallego, M., Tato, A., Osada, J., Muiño-Blanco, T., CebriánPérez, J., 2000. Seminal plasma proteins revert the cold-shock damage on ram sperm membrane. Biol. Reprod. 63, 1531-1537.

Barrios, B., Fernández-Juan, M., Muiño-Blanco, T., Cebrián-Pérez, J., 2005.

Immunocytochemical localization and biochemical characterization of two seminal plasma proteins that protect ram sperm against cold shock. J. Androl. 26, 539-549.

Bernardini, A., Hozbor, F., Sanchez, E., Fornes, M., Alberio, R., Cesari, A., 2011. Conserved ram seminal plasma proteins bind to the sperm membrane and repair cryopreservation damage. Theriogenology. 76, 436-447.

Bradford, M., 1976. A rapid and sensitive method for the quantification of microgram quantities of protein utilizing the principle of protein-dye binding. Anal. Biochem. 72, $248-254$. 
Cardozo, J., Fernández-Juan, M., Forcada, F., Abecia, A., Muiño-Blanco, T., CebriánPérez, J., 2006. Monthly variations in ovine seminal plasma proteins analyzed by twodimensional polyacrylamide gel electrophoresis. Theriogenology. 66, 841-850.

Colás, C., Junquera, C., Pérez-Pé, R., Pérez, J., Muiño-Blanco, T. 2009. Ultrastructural study of the ability of seminal plasma proteins to protect ram spermatozoa against coldshock Microscopy research and technique 72:566-572.

Desnoyers, L., Manjunath, P., 1992. Major proteins of bovine seminal plasma exhibit novel interactions with phospholipid. J. Biol. Chem. 267, 10149-10155.

Domínguez, M., Falcinelli, A., Hozbor, F., Sanchez, E., Cesari, A., Alberio, R., 2008. Seasonal variations in the composition of ram seminal plasma and its effect on frozenthawed ram sperm. Theriogenology. 69, 564-573.

Domínguez-Rebolledo, A., Navarrete Sierra, L., Cruz Tamayo, A., Aguiar Lorio, A., Erosa Denis, S., Bolio Oses, R., González Parra E., Paredes Monsreal, L., Ramón Ugalde J., 2007. Fertility in hair sheep inseminated with freeze spermatozoa rediluited with seminal plasma. Revista Científica $\mathrm{N}^{\circ} 1,73-76$.

Dott, H., Harrison, R., Foster, C., 1979. The maintenance of motility and the surface properties of epididymal spermatozoa of bull rabbit and ram in homologous seminal and epididymal plasma. J. Reprod. Fertil. 55, 13-24.

El-hajj Ghaoui, R., Thomson, P., Leahy, T., Evans, G., Maxwell, W., 2007. Autologous whole ram seminal plasma and its vesicle-free fraction improve motility characteristics and membrane status but not in vivo fertility of frozen-thawed ram spermatozoa. Reprod. Dom. Anim. 42, 541-549. 
Fernández-Gago, R., Domínguez, J., Martínez-Pastor, F., 2013. Seminal plasma applied post-thawing affects boar sperm physiology: a flow cytometry study. Theriogenology. $80,400-410$.

Fernández-Juan, M., Gallego, M., Barrios, B., Osada J., Cebrián-Pérez, J., MuiñoBlanco, T. 2013. Immunohistochemical Localization of Sperm-Preserving Proteins in the Ram Reproductive Tract. J. Androl. 27, 588-595.

Gillan, L., Evans, G., Maxwell, W., 1997. Capacitation status and fertility of fresh and frozen-thawed ram spermatozoa. Reprod. Fertil. Dev. 9, 481-487.

Graham, J., 1994. Effect of seminal plasma on the motility of epididymal and ejaculated spermatozoa of the ram and bull during the cryopreservation process. Theriogenology. $41,1151-1162$.

Green, C. and Watson, P., 2001. Comparison of the capacitation-like state of cooled boar spermatozoa with true capacitation. Reproduction. 122, 889-898.

Holt, W., Medrano, A., 1997. Assessment of boar sperm function in relation to freezing and storage J. Reprod. Fertil., 52, 213-222.

Laemmli, U., Beguin, F., Gujer-Kellenberger, G., 1970. A factor preventing the major head protein of bacteriophage T4 from random aggregation. J. Mol. Biol. 47, 69-85.

Leahy, J., Evans, G., W., 2010. Two-dimensional polyacrylamide gel electrophoresis of membrane proteins from flow cytometrically sorted ram sperm. Theriogenology. 75 , $962-971$.

Ledesma, A., Manes, J., Cesari, A., Alberio, R., Hozbor, F., 2014. Electroejaculation increases low molecular weight proteins in seminal plasma modifying sperm quality in Corriedale rams. Reprod. Dom. Anim. 49, 324-332. 
Ledesma, A., Cesari, A., Gil, J., Hozbor, F. b 2014. Efecto del método de colecta seminal sobre la composición proteica del plasma seminal ovino. $4^{\circ}$ Jornadas Internacionales del Instituto de Investigación y Tecnología en Reproducción AnimalINITRA, Buenos Aires, Argentina.

Marco-Jiménez F, Puchades S, Gadea J, Vicente J, Viudes de Castro M, 2005. Effect of semen collection method on pre and post-thaw Guirra ram spermatozoa.

Theriogenology. 64, 1756-1765.

Martínez-Pastor, F., Mata-Campuzano, M., Álvarez-Rodríguez, M., Álvarez, M., Anel, L., de Paz, P., 2010. Probes and Techniques for Sperm Evaluation by Flow Cytometry. Reprod. Dom. Anim. 45, 67-78.

Maxwell, W., Johnson, L., 1999. Physiology of spermatozoa at high dilution rates: the influence of seminal plasma. Theriogenology. 52, 1353-1362

Maxwell, W., de Graaf, S., Ghaoui, R., Evans, G., 2007. Seminal plasma effects on sperm handling and female fertility. Soc. Reprod. Fertil. 64, 13-38.

Mendoza, N., Casao, A., Pérez-Pé, R., Cebrián-Pérez, J., Muiño-Blanco, T. 2013: New Insights into the Mechanisms of Ram Sperm Protection by Seminal Plasma Proteins. Biol Reprod 88, 1-15

Ollero, M., Cebrián-Perez, J., Muiño-Blanco, T., 1997. Improvement of cryopreserved ram sperm heterogeneity and viability by addition of seminal plasma. J. Androl. 18, $732-739$.

Pérez-Pé, R., Cebrián-Pérez, J., Muiño-Blanco, T., 2001. Semen plasma proteins prevent cold-shock membrane damage to ram spermatozoa. Theriogenology. 56, 425434. 
Pérez-Pé, R., Grasa, P., Fernández-Juan, M., Peleato, M., Cebrián-Pérez, J., MuiñoBlanco, T., 2002. Seminal plasma proteins reduce protein tyrosine phosphorylation in the plasma membrane of cold-shocked ram spermatozoa. Mol Reprod Dev. 61, 226-33. Said, T., Gaglani, A., Agarwal, A. Implication of apoptosis in sperm cryoinjury. 2010. Reprod BioMed 21, 456-462.

Rodrigues, M., Souza, C., Martins, J., Rego, J., Oliveira, J., Domont, G., Nogueira, F., Moura, A. 2013. Seminal plasma proteins and their relationship with sperm motility in Santa Ines rams. Small Rum Res 109, 94-100.

Watson, P., 1981: The effects of cold shock on sperm cell membranes. In: Clarke A (ed.), Effects of Low Temperatures on Biological Membranes. Academic Press, London, pp. 189-218. 


\section{Tables and figures}

Fig. 1: Capacitation status by tyrosine phosphorylation in ram frozen/thawed sperm samples. Solubilized sperm protein from each treatment $\left(5 \times 10^{6}\right.$ cells $)$ were loaded and subjected to sodium dodecyl sulphate-polyacrylamide gel electrophoresis (SDS \pm PAGE) and immunoblotting of sperm protein extract with antiphosphotyrosine antibodies (Py); PVDF membranes were stripped, reblocked and incubated sequentially with an anti-tubulin antibody as a loading control (Tubulin). The experiment was performed four times on each season and a representative experiment is shown. Treatments were as follows: lane 1, seminal plasma (SP) obtained by artificial vagina (AV); Lane 2, seminal plasma obtained by electroejaculation (EE); Lane 3, interacting seminal plasma proteins (iSPP) obtained by artificial vagina; Lane 4, interacting seminal plasma proteins obtained by electroejaculation; Lane 5, control.

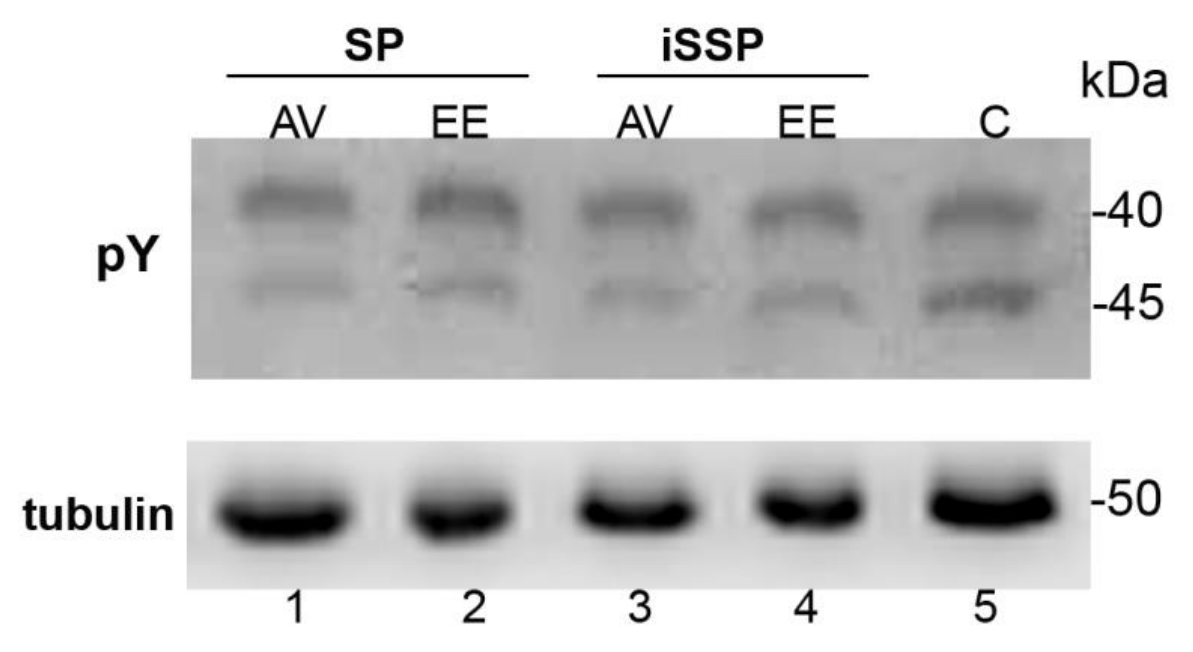


Table 1. Effect of addition of seminal plasma and interacting seminal plasma proteins collected by artificial vagina or electroejaculation on sperm motility parameters (mean \pm SEM). No interactions were observed only treatment effect is considered.

\begin{tabular}{|l|l|l|l|l|l|}
\hline Parameter & & SP EE & $\begin{array}{l}\text { iSPP collected } \\
\text { by AV }\end{array}$ & $\begin{array}{l}\text { iSPP collected } \\
\text { by EE }\end{array}$ & Control \\
\hline TM $(\%)$ & $74.13 \pm 2.99^{\mathrm{a}}$ & $72.27 \pm 2.99^{\mathrm{a}}$ & $60.07 \pm 2.99^{\mathrm{b}}$ & $53.92 \pm 2.99^{\mathrm{b}}$ & $54.30 \pm 3.01^{\mathrm{b}}$ \\
\hline PM $(\%)$ & $64.97 \pm 2.64^{\mathrm{a}}$ & $63.73 \pm 2.64^{\mathrm{a}}$ & $53.27 \pm 2.64^{\mathrm{b}}$ & $46.18 \pm 2.64^{\mathrm{b}}$ & $48.28 \pm 2.78^{\mathrm{b}}$ \\
VCL $(\mu \mathrm{m} / \mathrm{s})$ & $110.19 \pm 6.23^{\mathrm{c}}$ & $111.41 \pm 6.23^{\mathrm{c}}$ & $148.92 \pm 6.23^{\mathrm{ab}}$ & $136.76 \pm 6.23^{\mathrm{b}}$ & $159.67 \pm 6.26^{\mathrm{a}}$ \\
\hline VSL $(\mu \mathrm{m} / \mathrm{s})$ & $80.01 \pm 6.22^{\mathrm{b}}$ & $84.27 \pm 6.22^{\mathrm{b}}$ & $108.22 \pm 6.22^{\mathrm{a}}$ & $92.55 \pm 6.22^{\mathrm{b}}$ & $117.40 \pm 6.47^{\mathrm{a}}$ \\
\hline VAP $(\mu \mathrm{m} / \mathrm{s})$ & $95.47 \pm 5.61^{\mathrm{b}}$ & $98.14 \pm 5.61^{\mathrm{b}}$ & $119.44 \pm 5.61^{\mathrm{b}}$ & $105.50 \pm 5.61^{\mathrm{b}}$ & $130.82 \pm 5.84^{\mathrm{a}}$ \\
\hline LIN $(\%)$ & $76.66 \pm 2.76^{\mathrm{a}}$ & $78.08 \pm 2.76^{\mathrm{a}}$ & $73.71 \pm 2.76^{\mathrm{ab}}$ & $69.10 \pm 2.76^{\mathrm{b}}$ & $75.71 \pm 2.82^{\mathrm{a}}$ \\
\hline STR $(\%)$ & $87.95 \pm 1.10^{\mathrm{c}}$ & $89.28 \pm 1.10^{\mathrm{bc}}$ & $92.83 \pm 1.10^{\mathrm{a}}$ & $91.74 \pm 1.10^{\mathrm{ab}}$ & $93.06 \pm 1.12^{\mathrm{a}}$ \\
WOB $(\%)$ & $87.79 \pm 1.83^{\mathrm{a}}$ & $88.39 \pm 1.83^{\mathrm{a}}$ & $80.08 \pm 1.83^{\mathrm{b}}$ & $76.66 \pm 1.83^{\mathrm{c}}$ & $82.89 \pm 1.83^{\mathrm{b}}$ \\
\hline ALH $(\mu \mathrm{m})$ & $1.50 \pm 0.10^{\mathrm{b}}$ & $1.48 \pm 0.10^{\mathrm{b}}$ & $2.10 \pm 0.10^{\mathrm{a}}$ & $2.12 \pm 0.10^{\mathrm{a}}$ & $2.07 \pm 0.11^{\mathrm{a}}$ \\
\hline BCF $(\mathrm{Hz})$ & $22.58 \pm 0.79^{\mathrm{bc}}$ & $21.58 \pm 0.79^{\mathrm{c}}$ & $25.72 \pm 0.79^{\mathrm{a}}$ & $24.60 \pm 0.79^{\mathrm{ab}}$ & $25.79 \pm 0.84^{\mathrm{a}}$ \\
\hline
\end{tabular}

SP: seminal plasma; AV: artificial vagina; EE: electroejaculation; TM: total motility percentage;

PM: progressive motility percentage; VCL: curvilinear velocity; VSL: straight line velocity;

VAP: average path velocity; LIN: linearity; STR: straightness; WOB: wobble; ALH: lateral head displacement; BCF: beat cross frequency. Values in the same row with different superscripts $(\mathrm{abc})$ are statistically different $(\mathrm{p}<0.01)$. 
Table 2. Effect of addition of seminal plasma and interacting seminal plasma proteins collected by artificial vagina or electroejaculation on sperm quality parameters (mean \pm SEM). No interactions were observed between season and treatment.

\begin{tabular}{|l|l|l|l|l|l|}
\hline \multirow{2}{*}{$\begin{array}{l}\text { Parameter } \\
(\%)\end{array}$} & SP AV & SP EE & $\begin{array}{l}\text { iSPP collected } \\
\text { by AV }\end{array}$ & $\begin{array}{l}\text { iSPP collected } \\
\text { by EE }\end{array}$ & Control \\
\hline PI-/ YO-PRO-1- & $44.60 \pm 2.87^{\mathrm{a}}$ & $35.80 \pm 2.47^{\mathrm{b}}$ & $27.02 \pm 2.70^{\mathrm{c}}$ & $26.25 \pm 2.64^{\mathrm{c}}$ & $25.20 \pm 2.10^{\mathrm{c}}$ \\
\hline YO-PRO-1-/ M540- & $44.56 \pm 2.49^{\mathrm{a}}$ & $36.67 \pm 1.71^{\mathrm{b}}$ & $27.23 \pm 2.24^{\mathrm{c}}$ & $27.09 \pm 2.154^{\mathrm{c}}$ & $25.32 \pm 2.14^{\mathrm{c}}$ \\
\hline YO-PRO-1-/ MT+ & $41.87 \pm 4.89^{\mathrm{a}}$ & $37.40 \pm 2.45^{\mathrm{a}}$ & $27.06 \pm 2.35^{\mathrm{b}}$ & $28.27 \pm 2.66^{\mathrm{bc}}$ & $26.17 \pm 1.57^{\mathrm{b}}$ \\
\hline PI-/CM-H2DCFDA- & $23.52 \pm 4.63^{\mathrm{b}}$ & $32.66 \pm 4.12^{\mathrm{a}}$ & $24.39 \pm 4.81^{\mathrm{b}}$ & $22.72 \pm 3.99^{\mathrm{b}}$ & $20.92 \pm 4.20^{\mathrm{b}}$ \\
\hline
\end{tabular}

AV: artificial vagina; EE: electroejaculation; $\mathrm{PI} / \mathrm{CM}-\mathrm{H}_{2}$ DCFDA: live sperm with formation of oxygen free radicals; YO-PRO-1-/M540-: live sperm with low membrane fluidity; YO-PRO-1/MT+: viable sperm with high mitochondrial membrane potential; PI-/YO-PRO-1- viable, normal membrane permeability. Values in the same row with different superscripts (abc) are statistically different $(\mathrm{p}<0.05)$. 
Table 3. Effect of addition of seminal plasma and interacting seminal plasma proteins collected by artificial vagina or electroejaculation on densitometry quantification of the phosphorylation signal normalized with antitubulin antibody (mean \pm SEM).

\begin{tabular}{|l|l|l|l|l|l|}
\hline $\begin{array}{l}\text { Protein } \\
\text { band }(\mathrm{kDa})\end{array}$ & SP AV & SP EE & $\begin{array}{l}\text { iSPP collected } \\
\text { by AV }\end{array}$ & iSPP collected & \\
\hline 45 & $0.17 \pm 0.03^{\mathrm{c}}$ & $0.13 \pm 0.03^{\mathrm{c}}$ & $0.21 \pm 0.035^{\mathrm{b}}$ & $0.36 \pm 0.15^{\mathrm{b}}$ & $0.65 \pm 0.21^{\mathrm{a}}$ \\
\hline 40 & $0.37 \pm 0.14^{\mathrm{c}}$ & $0.38 \pm 0.14^{\mathrm{c}}$ & $0.38 \pm 0.14^{\mathrm{c}}$ & $0.53 \pm 0.14^{\mathrm{b}}$ & $0.77 \pm 0.14^{\mathrm{a}}$ \\
\hline
\end{tabular}

AV: artificial vagina; EE: electroejaculation. Values in the same row with different superscripts $(a b c)$ are statistically different $(p<0.05)$. 